Mohammad Osman Gani, Assistant Professor, Department of Marketing, Bangladesh University of Professionals, Dhaka, Bangladesh, Graduate Student, Hiroshima University, International Development and Cooperation, Higashihiroshima-Shi, Kagamiyama, Hiroshima

Mohammad Zahedul Alam, Ph.D., Associate Professor, Department of Marketing, Bangladesh University of Professionals, Dhaka, Bangladesh

Md. Mahabub Alom, Assistant Professor, Manarat International University, Dhaka, Bangladesh

Mohammad Omar Faruq,

Ph.D. applicant, Assistant Professor, Department of Accounting \& Information Systems, Jagannath University, Dhaka, Bangladesh

\title{
CHALLENGES AND PROSPECTS OF NEUROMARKETING: BANGLADESH PERSPECTIVE
}

For improving marketing effectiveness, the producers and entrepreneurs today want to understand how human psychology and emotions influencing on decision making. In this instance, the concept of neuromarketing offers a chance to get accurate, factual data about the buying habits of target markets. This study has been intended to explore the challenges, prospects, limitation and potentiality of practising neuromarketing in the context of Bangladesh as a cutting-edge marketing issue with the purpose of providing corresponding recommendations. The status and future prediction of neuromarketing have been exposed through qualitative and quantitative analysis. The finding of the study has been supported by collecting data from 55 customers and 65 marketers as the respondents. The key findings of this study are quite impressive and prospective regarding the level of awareness, interest, acknowledgement and conviction towards practising neuromarketing in the context in Bangladesh. The contribution of this study can be breakthrough and pave the way for neuromarketing in Bangladesh. The findings of this study will be helpful for the marketing policy makers and govt agencies to introduce this new method of marketing tools in Bangladesh. Finally, some policy guidelines were provided based on findings and analysis. In that way, marketers have to promote initiatives to familiarize the devices of the neuromarketing, have to engage the educated customers to share their experiences while designing the marketing strategies and plans. The important conclusion that the education is one of the most important factors affecting the adoption of the neuromarketing practice. On the other hand, marketers should take initiatives to overcome some misconceptions regarding the harmful for the brain activity devices of the neurology.

Keywords: neuromarketing, marketing, marketing research, consumer perception.

Introduction. Neuromarketing has started its journey as an interdisciplinary interface and relatively new research discipline in 2002 with growing attention of companies, advertiser and marketers (Morrin 2011, Reimann et.al, 2011, Bercea, 2014, Lee et. al., 2007). It is a paradigm shift in the field of marketing science. In this era of overloaded information, as a traditional marketing research tools and technique-such as a focus group, interview method, customer survey, and questionnaire method are not being considered as a reliable and scientific source of information for practising of decision making (Morrin, 2012). In reality, what people say and their brain says both are quite different. Neuromarketing deals with unconscious and clandestine information about customer thoughts, feelings and emotions through the study of brain activity. It can generate more genuine and authentic predictions about customer's preferences and choices. Apart from traditional market research, neuromarketing eradicates 
subjectivity and become subject to examining brain regions activity and predicting high-levels of product purchasing decisions (Lee, Broderick, \& Chamberlain, 2007). Instead of opinion, neuromarketing measures the attention level, emotional engagement and memory storage. Neuromarketing uses the latest advanced technologies for brain scanning intending to know more about the mental and thinking processes of customer purchasing decisions and helps to match the desired offerings (Ariely et al.2010).

In Bangladesh perspective, this concept is quite unfamiliar and alienate because of not having awareness and lack of infrastructure for practice. But more than 160 million population of Bangladesh with its enviable position and economic resilience has created the great market potential for national and multinational companies. Growing steady rate of GDP, a substantial number of mobile phone users, the proliferation of TV channel and FM radio, lucrative geopolitical location, conterminous language, culture and cushiness have created a great melody in the marketplace of Bangladesh. Even not only Socio-economic but also religious-cultural forces reshape the aspirations and habits of Bangladeshi customers. Since marketing can cause buy something, myriads of national and multinational companies adopt the different approach of marketing practices to operate their business activities within the context of changing macro environments in Bangladesh. To remain competitive in Bangladeshi marketplace and reap the benefit, they asses continually the environment and adjust their marketing strategies and tactics in the response to the ever-changing market. In this exigency, neuromarketing can provide great insights about Bangladeshi customers to practice marketing efficiently and effectively. Not only that, all techniques and tools of neuromarketing can map out brain patterns and help to understand the thinking and reaction of customers towards marketing offerings and decision making from Bangladesh perspective.

Literature Review. Neuromarketing is a contemporary breakthrough in the field of marketing science. It is a sort of predictions and response to a stimulus. It can map out the brain patterns, study the image over word, experience over explanation because it is an intriguing marriage of marketing and science. It connects the consumer with marketer utilizing science as the key to unlock of human latent intent. It is an instrument to decode what consumer thinking in their brain (Lindstrom, 2008). It is a brain scanning to control the consumer's brain. In neuromarketing practices, marketing and science come together to help companies, advertisers, marketers etc. Through brain scanning experiment, neuromarketing can extract the insights of customer hidden preferences, unconscious desires and irrational dreams (Lindstrom, 2008).

In today's competitive marketing environment, companies are now indicating towards the value of using marketing science to uncover the latent demand of human behaviour for their survival. In that case, neuromarketing as a science of understanding consumer psychology can help to practice of using different technologies to measure the activities of the brain of the consumer as a way that discover how people are responding towards marketing offerings and messages at different circumstances (Randall, 2009). It has exposed customer tendencies and preferences through extracting great inputs and insights what customer need and value. By utilizing the advanced technology, neuromarketing encroaches conventional tools of marketing (quantitative and qualitative) research and brings into a reality (Romero L.C. et al., 2016; Falk et al. 2012). Giving the focus on consumer's brain reactions in respect of marketing stimuli and brand choice researchers can easily identify their desire (Bakardjieva \& Kimmel, 2017; Fisher et al., 2010). Understanding the subconscious areas of the human brain, marketers and advertisers can make predictions on what people want and eventually marketers can alter products and messages most likely to attract and retain customers (Nobel, 2013; Randall \& Kevin, 2009). Neuromarketing measures response of the consumer's brain to advertising messages as well as help to acquire pertinent information about the inner thinking's (Morin, 2011: Murphy et.al, 2008; Burne, 2003; Shah, 2005). Neuromarketing is the utilization of neuroimaging techniques to understand human behaviour (Lee, Broderick, \& Chamberlain, 2007; Weinstein, Drozdenko, \& Weinstein, 1984). Neuromarketing is the combination of neuroscience and marketing practices. Moreover, marketing researchers are using some imaging technologies like (PETpositron emission tomography, MEG- magneto encephalography, FMRI- functional magnetic resonance 
imaging, EEG- electroencephalography, GSR- galvanic skin response) to measure emotions and record responses of the human brain to different stimuli (Lee et al. 2009 p: 199, Arussi 2009). Lewis (2004) affirms two most important techniques of analyzing human brain activities that are used in neuromarketing - fMRI (functional magnetic resonance imaging) and other researchers like Poldrack et al. (2008); Haynes and Rees (2006) mentioned about EEG. Vechiatto et al. (2011) focused on utilizing a variety of neuroimaging techniques such as QEEG (Quantitative electroencephalography), SST (Steady State Topography) ERP (Event Related Potentials) and SSPT (Steady State Probe Topography) to determine the latent purchase intention or brand choice determination. Scientific researchers in the field of neuromarketing have sought to better understand on the decision-making processes of individuals by utilizing all these technologies (Agarwal and Dutta, 2015). Through neuromarketing, marketers can claim whether a product or a campaign will be successful through their experiments by applying imaging technology on customers (Gani et al., 2015). On the other hand, Mindmetic's technology using in neuromarketing technology helps to understand consumer's reactions (Email W., 2009). So now it is decisive that, with the combination of neuromarketing techniques and traditional research techniques it will be easier for the marketers to get the insights of a customer and marketers can make their decision (Sarigiannidou and Vlachakis, 2017).

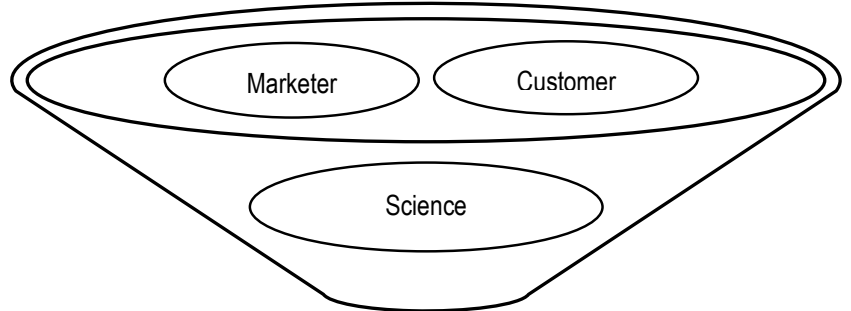

Figure 1 - Neuromarketing Interface

Neuromarketing is not the interview of the customer rather it is the interview of customer's brain. Neuromarketing techniques are widely used for testing the effect of marketing stimuli on the consumer's brain (Smidts et al., 2014). The relationship between brain activity and behaviour with cognition has been measured through neuromarketing (Reimann et al., 2011, Lee, Broderick, \& Chamberlain, 2007; Weinstein, Drozdenko, \& Weinstein, 1984). Williams (2010) refers that neuromarketing research is usually conducted through one or more of the following clinical techniques-

1. (Functional) Magnetic Resonance Imaging(fMRI): It has become a popular way of measuring psychology from the last decade (Bercea D. M. 2014; Lee.N et al.2009) as a cognitive neuroscience (Huettel, S. A. et al., 2004). fMRI helps marketer by measuring: sensory perception, memory encoding, brand recall, brand preference, brand loyalty, craving, trust, understanding of advertising (Lee.N et al.2009; lorga M.A. \& Pop Al.N.,2012). fMRI usually uses for testing new product performance, new campaigns, developing new advertising process, packaging design, testing product prices, finding market needs, positioning and repositioning the brands (Kenning, P. et al.,2007: Yoon, C. et al, 2006; Breiter and Rosen, 1999).

2. Electroencephalography (EEG): Neurological science uses it for identifying, recording (Voicu, C.M., 2013) and measuring brain waves (lorga M.A. \& Pop Al. N. (2012) produced by the cortex, reflecting the positive or negative emotions. It records brainwaves through imaging (Vecchiato, $G$ et al., 2010; Fugate,2007) correspond to certain mental states (Norris and Currieri, 1999), such as relaxation (alpha waves), sleep (delta waves), wakefulness (beta waves), calmness (theta waves). It measures emotional valence (Harmon-Jones and Allen, 1998), cognition (Babiloni, C. et al., 2002), memory encoding 
(Bergner,W. M. et al.,2006), recognition (Lotte, F.et al.,2007; Gevins and Smith,1999), attention, engagement / boredom ( Hondrou and Caridakis, 2012; Wang \& Hsu, 2014), excitement, records surface activity of brain wave, decision-making mechanism (Heekeren, H. R. et al.,2008) allow to measure interest of any product. EEG usually used for identifying the key point of advertising (O'Connel et al. 2011; Ohme, R.2009) or video material, testing and developing advertisements, testing new campaigns, product moment of correlation (Vechiatto et al. 2011) testing in-store experience, testing websites design and usability, testing taglines etc.

3. Magnetoencephalography (MEG): MEG measures the area of magnetic fields (lorga M.A. \& Pop AL. N., 2012) generated by the brain's electrical functioning (Lee N. et al, 2009), allowing the potential to measure activity throughout the brain by synchronizing neurons (Roullet and Droulers, 2010). Magnetic field helps us to measure perception, attention, attitude (Caldas.C. et al., 2009) and memory basically a measurement of extremely weak magnetic fields (Hamalaainen and Hari, 2002). Marketers usually use MEG when testing a new product, test advertising, identify sensory measurement.

4. Positron emission tomography (PET): PET measures sensory perception, the valence of emotions, energy discrimination, and improvements in attenuation correction for measuring consumers demand (Bercea D. M. (2014). Now day marketers are using PET technology, though it is an expensive method (Sebastian, 2014). It also helps in advertising development and maintaining sequence, testing new campaigns feasibility, product moment of correlation (Ter-Pogossian, 2017; Mathis, C. A et al., 2002).

5. Transcranial magnetic stimulation (TMS): TMS is a neurophysiologic technique that allows for noninvasive stimulation of the human brain which helps in creating a healthy participatory mode (Horvath et al., 2011; Walsh and Cowey, 2000). TMS increasingly used for measuring the changes in behaviour, getting attention to cognition, recognition, attention, and engagement/boredom. On the other hand, it's not a brain imaging technology (Senior, 2007). TMS has been used to study the causal role of specific brain regions by temporarily taking them 'offline' (Ariely, D, 2010) which inducing a brief electrical current in areas of the cortex (Senior, 2007). It also helps in advertising development, testing new campaigns feasibility, product moment relationship and correlation (Hallett, M., 2000).

6. Eye Tracking: Eye Tracking (ET) is using from a long time in marketing research (Santos, O.R. et al, 2015) and it has multiple uses in business (Zhao \& Koch, 2013; Wedel and Pieters, 2008). People have an enormous interest in ET issues for measuring consumers interest (Martinez, 2011; Solnais et al., 2013). It is a tool for analysing visual attention (Khushaba et al., 2013). It deals with the psychological significance, and the behavioural consequences of the consumers (Reimann et al., 2011; Laubrock et al. 2007). It measures the movement of one's eye relation to his head, pupil dilation, the number of blinks (Zurawicki, 2010; Duchowski, A. T., 2007), fixation and saccades (Velásquez, 2013), the sequence of eyes shift from one location to another (Chae \& Lee, 2013), measure the observation of controlled stimuli at fixed points in videos, photos, and user's interaction (Zurawicki, 2010) in many different marketing issues (Fiszman, Velasco, Salgado-Montejo, \& Spence, 2013). ET helps in purchasing decision making (Orquín and Loose, 2013; Maughan, L. et al., 2007).

7. Measuring Physiological Responses: MP indicators are the oldest and simplest technique using as a means of measuring consumer responses (Camerer et al., 2005). Some emotional issues help marketers to understand the behaviour and decision-making process regarding the purchasing issue (Bercea, D. M., 2013). Monitoring customers heart rate, blood pressure, blood circulation, skin conductivity, a hormone from saliva, facial muscles contractions researchers can infer the emotional state for each moment and emotional attachment during purchasing (Mollen and Wilson, 2010). "Facial Electromyography (EMG) can be used to measure the emotional response of the face" (Kenning \& Linzmajer, 2011).

8. Implicit association test: It has a long history which infers unstated processes and responses for measuring individual's behaviour and experience (Bercea, D. M. 2013; Smith and Nosek, 2010; Greenwald et al., 2003). The approach measures consumers' reaction times or accuracy on tasks that are 
systematically biased by their reactions to brands or ads (Page, G. 2011; Hofmann et al., 2005) and also measures the attitude of the buyers (Houwer \& Bruycker, 2007). According to Bercea, D. M. (2014)-

"IAT measures the underlying attitudes (evaluations) of the subjects by assessing reaction times on two cognitive tasks, identifying the speed with which they can associate two different concepts (stimuli such as advertisements, brands, concepts) with two different evaluative anchors (attributes) is computed."

9. Skin conductance (SC): It has recently received enormous attention in the field of social sciences due to the ability to capture information from the human body (Ledowski et al., 2006; Benedek and Kaernbach, 2010; Van Dooren and Janssen, 2012). SC is based on the analysis of subtle changes in galvanic skin responses (GSR) when the autonomic nervous system (ANS) is activated (Park, S. H. et al., 2018; Kuan, G. et al., 2018; Dehzangi, et al.,2018; Ohme et al. 2009; McBride et al., 1965). It measures the emotional states by touching the skin with different measurement techniques (Karibe, $\mathrm{H}$ et al., 2018; Lai, C. F. et al., 2018). It arouses the responses on different circumstances which can help to predict buyer behaviour varying different products (Duan et al., 2018; Petty, R. E. (2018; Stasi, A et al.,2018).

Using of above tools and techniques of neuromarketing can contribute to launch a new product successfully, design the store ambience, effective practice of integrated marketing communication, and anticipate demand and marketing return on investment through suitable prediction of customer preferences and choices. Vivian Roth (2013) has exposed some influences of neuromarketing on consumer purchase decision and choice (Koc and Boz, 2018)., advertising and promotion (Daugherty et al., 2018), pricing and choice on discounted items (Alvino, L. et al., 20018) , distribution and channelling (Lewandowska, A et al., 2018), branding (Singh and Jain, 2018)., new product innovation and product design (Suomala, 2018). Rafiq and Masum (2006) have highlighted the prospects of neuromarketing as closing the sales and marketing gap, building brand images, new product development, marketing communication and risk-taking behaviour.

Nations all around the world have initiated and launched brain-mapping projects on a large scale and mentioned the technological world and its success (Bonner, 2015). Despite having numerous benefit and significant application of neuromarketing, Bangladeshi customers and marketers have not witnessed and experienced with the concept till now. But the practice of neuromarketing concept can explore and explain the preferences and choices of the customer towards markers offerings and marketing stimuli. Through applying the concept, national and multinational companies of Bangladesh can anticipate the market demand and marketing return on investment (ROI). Although neuromarketing has spilt over on mainstream marketing practices, it is still in an inchoative stage globally. In Bangladesh, marketers, customers and academicians have ambivalent attitudes towards the practices of neuromarketing and all stakeholders are well-familiar or well-tuned with the concept. Despite, availability of new technology, the quest for sustainable competitive advantages and to understand Bangladeshi customers, national and multinational companies need to practice neuromarketing. With having that aim, this study has attempted to explore untapped prospects with its challenges as the tipping point for neuromarketing practices in Bangladesh. Not only that, but it can also pave the way for future practices of neuromarketing after having so many challenges.

The objective of the Study. We posit the objective of this study is to explore the challenges and prospects of neuromarketing from Bangladesh perspective. The other specific objectives are: to expose the challenges of practising neuromarketing in Bangladesh from customer and marketer perspective; to explore the potentiality of practising neuromarketing in Bangladesh from customer and marketer perspective; to provide some recommendations regarding neuromarketing practices in Bangladesh.

Research Methodology. This study is exploratory in nature. Both qualitative and quantitative research approaches have been used as a research methodology for this study. Data has been collected from primary and secondary sources. To fulfil the requirements of the objective, a questionnaire was prepared and surveyed to collect data from customers and marketers respectively. Since the population of this study 
was not that much larger, as a sampling technique, this research applied a convenience sampling procedure which is a type of nonprobability sampling where the sample is taken from a group of people easy to contact or to reach (Lavrakas, 2008). This research also applied a personal approach to motivate the respondents to participate in the survey, with the objective of getting a high response rate. Basically, a self-administered survey questionnaire has been used to unearth the reality and existing level of awareness of customers and marketers towards neuromarketing in Bangladesh. The separate set of questionnaires have been developed for customers and marketers based on reviewing related literature and expert opinions. The questions have been grouped into four sections based on demographic profiles, feelings, interests and awareness of customer and marketer towards neuromarketing. Therefore, the total respondents were 66 from customers and 54 from marketers and they were selected based on convenient sampling. Data analysis was conducted through descriptive analysis followed by SPSS software highlighting binary logistic regression analysis.

Findings and Interpretations. Demographic Profile of the Respondents (Customers and Marketers). The demographic characteristics of the respondents are shown in Table-I. A summary of findings on respondents' profile along four variables: gender, age, marital status and academic qualification has been presented in the Table 1. It has been found that most of the respondents are male from both clusters of customers and marketers. The table shows a high concentration of respondents from customers belong to the age category 21-30 years. And respondents of age group 21-30 and 31-40 years are mentionable from marketers. As a marital status, majority respondents from customers are single but married respondents are more than single from marketers. Furthermore, the table presents that in terms of academic qualification, $62.1 \%$ respondents are graduate students from customers cluster and respondents from marketers undergraduate as well as graduates are quite similar.

Table 1 - Demographic Variable of Respondents (based on Field Survey, 2017)

\begin{tabular}{|c|c|c|c|c|c|}
\hline Variables & Structures & $\begin{array}{c}\text { Respondents } \\
\text { from Customers }\end{array}$ & $\begin{array}{c}\text { Respondents } \\
\text { from Marketers }\end{array}$ & $\begin{array}{c}\text { Indicators of } \\
\text { Customers }\end{array}$ & $\begin{array}{c}\text { Indicators of } \\
\text { Marketers }\end{array}$ \\
\hline \multirow{2}{*}{ Gender } & Male & 45 & 42 & $68.2 \%$ & $77.8 \%$ \\
& Female & 21 & 12 & $31.8 \%$ & $22.2 \%$ \\
\hline \multirow{3}{*}{ Age } & $21-30$ Years & 62 & 33 & $97 \%$ & $61.1 \%$ \\
& $31-40$ Years & 2 & 20 & $3 \%$ & $37.0 \%$ \\
& $41-51$ Years & 0 & 1 & $0 \%$ & $1.9 \%$ \\
Marital Status & Above 51 Years & 0 & 26 & $74.2 \%$ & $48.1 \%$ \\
& Single & 49 & 28 & $25.8 \%$ & $51.9 \%$ \\
\hline \multirow{3}{*}{ Academic } & Married & 17 & 24 & $10.6 \%$ & $44.4 \%$ \\
Qualification & Under Graduate & 7 & 23 & $62.1 \%$ & $42.6 \%$ \\
& Graduate & 41 & 3 & $27.3 \%$ & $5.6 \%$ \\
\end{tabular}

Table 2 - Level of awareness, interest, acknowledgement and conviction regarding the Neuromarketing in Bangladesh (based on Field Survey, 2017)

\begin{tabular}{|c|c|c|}
\hline Dimensions & Yes & No \\
\hline Awareness & 10 & 44 \\
\hline Interest & 50 & 4 \\
\hline Acknowledgement & 49 & 5 \\
\hline Conviction & 50 & 4 \\
\hline
\end{tabular}

From the above the table, it is illustrated that most of the marketers are not aware of the neuromarketing practices, but they are very much interested regarding the neuromarketing and willing to practice this method and they have confidence regarding the adoption of this method. 
Table 3 - Level of awareness regarding the devices of Neuromarketing (based on Field Survey, 2017)

\begin{tabular}{|c|c|c|c|c|c|c|c|c|c|}
\hline & fMRI & EEG & MEG & PET & TMS & ET & MPS & IAT & SC \\
\hline Yes & $20 \%$ & $8 \%$ & $6 \%$ & $3 \%$ & $2 \%$ & $72 \%$ & $19 \%$ & $18 \%$ & $6 \%$ \\
\hline No & $80 \%$ & $92 \%$ & $94 \%$ & $97 \%$ & $92 \%$ & $28 \%$ & $81 \%$ & $92 \%$ & $94 \%$ \\
\hline
\end{tabular}

From the above table, it is revealed that most of the devices used for Neuromarketing are not known to marketers; even they did not hear the name of the devices early.

Binary Logistic Regression. For analysing the dichotomous questions, Binary logistic regression is run to find out the coefficient of dependent variables (i.e. Neuromarketing) on independent variable (i.e. ages, education and product categories).

Table 4 - Customers View Regarding Neuromarketing Practices

\begin{tabular}{|l|l|c|c|c|c|c|c|}
\hline \multicolumn{2}{|c|}{ Variables in the Equation } & B & S.E. & Wald & df & Sig. & Exp(B) \\
\hline \multirow{4}{*}{ Step 1a } & Education & .948 & .753 & 1.587 & 1 & .208 & 2.581 \\
\cline { 2 - 8 } & Ages & .112 & .675 & .028 & 1 & .868 & 1.119 \\
\cline { 2 - 8 } & Product_Categories & .077 & .346 & .049 & 1 & .824 & 1.080 \\
\cline { 2 - 8 } & Constant & -2.625 & 1.262 & 4.331 & 1 & .037 & .072 \\
\hline
\end{tabular}

The estimated value of $\beta 1=.948$ which implies that the estimated change in the logit/log-odds for levels of education is .948 than not involve in neuromarketing and $\operatorname{Exp}(\beta 1)=2.581$, which implies that levels of education are 2.581 times as likely to practice Neuromarketing i.e. those who are not educated.

The estimated value of $\beta 2=.112$, which implies that the estimated change in the logit/log-odds for every change of 1 age is .112 and $\operatorname{Exp}(\beta 2=1.119)$, which implies that for every increase of 1 year of Age, the outcome of practising neuromarketing increases 1.119 times. On the other hand, we can say that for 1 increase of Ages, the output of practising neuromarketing is $1 \%$.

The estimated value of $\beta 3=.077$, which implies that the estimated change in the logit/log-odds for every change of product category, the practice of neuromarketing is .077 and Exp ( $\beta 3=1.108)$, which implies that for every increase of product category, the outcome of practising neuromarketing increases 1.108 times. On the other hand, we can say that for 1 increase in product categories, the output of practising neuromarketing is $.108 \%$.

Table 5 - Marketers View Regarding Neuromarketing Practices

\begin{tabular}{|l|l|c|c|c|c|c|c|}
\hline \multicolumn{2}{|c|}{ Variables in the Equation } & B & S.E. & Wald & df & Sig. & Exp(B) \\
\hline \multirow{4}{*}{ Step 1a } & Education & 1.830 & 1.081 & 2.865 & 1 & .091 & 6.233 \\
\cline { 2 - 8 } & Ages & 1.014 & .943 & 1.157 & 1 & .282 & 2.758 \\
\cline { 2 - 8 } & Product_Categories & -1.491 & 1.548 & .928 & 1 & .335 & .225 \\
\cline { 2 - 8 } & Constant & -2.524 & 3.517 & .515 & 1 & .473 & .080 \\
\hline \multicolumn{2}{|l|}{ a. Variable(s) entered on step 1: Education, Ages, Product_Categories } \\
\hline
\end{tabular}

The estimated value of $\beta 1=1.830$ which implies that the estimated change in the logit/log-odds for levels of education is 1.830 than not involve in neuromarketing and $\operatorname{Exp}(\beta 1)=6.233$, which implies that levels of education are 6.233 times as likely to practice neuromarketing i.e. those who are not educated.

The estimated value of $\beta 2=1.014$, which implies that the estimated change in the logit/log-odds for every change of 1 Ages is 1.014 and $\operatorname{Exp}(\beta 2=2.758)$, which implies that for every increase of 1 year of Age, the outcome of practising neuromarketing increases 2.758 times. On the other hand, we can say that for 1 increase of Ages, the output of practising neuromarketing is .758\%. The estimated value of $\beta 3=$ 1.491 which implies that the estimated change in the logit/log-odds for every change of product category, the practice of neuromarketing is 1.491 and $\operatorname{Exp}(\beta 3=.225)$, which implies that for every increase of product categories, the outcome of practising neuromarketing increases .225 times. On the other hand, we can say 
that for 1 increase in product categories, the output of practising neuromarketing is $.225 \%$.

Recommendations and Suggestions. Based on the findings, researchers have arrived at some recommendations and suggestions such as are: marketers should talk about some initiatives to familiarize the devices of the neuromarketing in the marketplace and market space; companies should engage the educated customers in the neuromarketing campaign program where they can share their experiences while designing the marketing strategies and plans; education is one of the most important factors affecting the adoption of the neuromarketing practices. So well-educated customers should be targeted for the luxurious goods where neuromarketing devices will be adopted; some customer has a misconception about the devices of neuromarketing practices, they think that these devices will be harmful to the brain activity. Marketers should take initiatives to overcome these misconceptions regarding the devices of the neurology.

Policymakers can educate the public by providing information about neuromarketing devices. Our study reveals consumers' attitude towards neuromarketing and in general, it has become a demanding issue regarding the intention of using neuromarketing devices (Eser, $Z$ et al., 2011). Some ethical issues are still the matter of concern (Ulman et al., 2015). From this study, marketers will understand the challenges and limitations while adopting the neuromarketing practices in the context of Bangladesh.

Limitations of the Study and Future Research Directions. As Bangladesh is a developing country using neuromarketing tools still have some difficulties. People are still lag behind the knowledge of neuromarketing. Neuromarketing is one of the new dimensions of marketing practices still not very familiar in developing countries (Saad, 2015). Majority of the respondents are not aware of this technique eventually they don't have any trust in these devices (Zak and Knack, 2001). So, it was very difficult to collect the data from the respondents. There are some beau acritical difficulties still lies in some progressing countries before using these devices (Oliveira de, 2014). The findings of the study cannot be generalized due to the small size of the respondents. Clearly, our findings provide some clear ideas that are deserving of future research in Bangladesh, and it could be replicated for the future research. Further research may be conducted on the specific application of neuromarketing devices for high-tech firms, SMEs and fast-moving consumer goods (FMCG) related firms to get more customer insights. Creation of awareness is still challenging due to the fear and lack of knowledge of the devices (Fortunato et al., 2014). Further study can only be conducted on knowledge creation process of the customer regarding these tools and to make accustomed the firms with the adaptation of using these technological tools for future demand creation.

Conclusion. Neuromarketing is a great shift from conscious world to the unconscious world, visible to invisible and traditional to cutting-edge marketing research (Nemorin, 2017). In the question of fruitions application, neuromarketing is not beyond the implications. People are concern about neuromarketing in terms of privacy, security, manipulation. The cost also remains as barriers. Despite the ambivalent attitude, choosing the right tools and making integration with other tools can ensure best possible results in the practice of neuromarketing. So, considering the situation and research type it is necessary to apply the neuromarketing techniques inappropriate situation. In behavioural science, it is tough to find out the actual reasoning of an action. People with inquisitive nature always attempts to find out the insights. The instruments are widely used in measuring consumer behaviour and they add value to traditional marketing research techniques. It's clear that by applying neuromarketing tools, marketing researchers can uncover the latent human needs and influences on their decision-making process, even the things that are unaware to them.

Agarwal, S., \& Dutta, T. (2015). Neuromarketing and consumer neuroscience: current understanding and the way forward. Decision, 42(4), 457-462.

Alvino, L., Constantinides, E., \& Franco, M. (2018). Towards a Better Understanding of Consumer Behavior: Marginal Utility as a Parameter in Neuromarketing Research. International Journal of Marketing Studies, 10(1), 90.

Ariely, D. \& Berns, G. (2010). Neuromarketing: the hope and hype of neuroimaging in business. Nature Reviews Neuroscience, 11(4), 284-292. 
Arussy L. (2009). "Neuromarketing Isn't Marketing", Customer Relationship Management, Information Today Inc.

Babiloni, C., Babiloni, F., Carducci, F., Cincotti, F., Cocozza, G., Del Percio, C., \& Rossini, P. M. (2002). Human cortical electroencephalography (EEG) rhythms during the observation of simple aimless movements: a high-resolution EEG study. Neuroimage, 17(2), 559-572.

Bakardjieva, E., \& Kimmel, A. J. (2017). Neuromarketing research practices: attitudes, ethics, and behavioral intentions. Ethics \& Behavior, 27(3), 179-200.

Baxter, M.G. \& Murray, E.A. (2002) The amygdala and reward. Nature Reviews Neuroscience, 3: 563-573

Benedek, M., \& Kaernbach, C. (2010). Decomposition of skin conductance data by means of nonnegative deconvolution. Psychophysiology, 47(4), 647-658.

Bercea, D. M. (2013). "Quantitative versus qualitative in neuromarketing research", Alexandru loan Cuza" University, Faculty of Economics and Business Administration, Department of Marketing, lasi, Romania, Online at- http://mpra.ub.uni-muenchen.de/44134.

Bercea D. M. (2014). "Anatomy of methodologies for measuring consumer behavior in neuromarketing research", "Alexandru loan Cuza" University of laşi, Romania.

Bonner, A. M. (2015). The use of neurodiagnostic technologies in the 21 st-century neuroscientific revolution. The Neurodiagnostic Journal, 55(1), 46-53.

Breiter, H. C., \& Rosen, B. R. (1999). Functional magnetic resonance imaging of brain reward circuitry in the human. Annals of the New York Academy of Sciences, 877(1), 523-547.

Burne, J. (2003). Inside the mind of the shopper: Neuromarketing: Brain scans now offer the slightly alarming prospect of marketers being able to track the deepest desires of consumers and target their advertising accordingly. Financial Times, p. 13.

Camerer, C., Loewenstein, G., \& Prelec, D. (2005). Neuroeconomics: How Neuroscience Can Inform Economics. Journal of Economics Literature, XLIII, 9-64.

Castro-Caldas, A., Nunes, M. V., Maestú, F., Ortiz, T., Simoes, R., Fernandes, R., ... \& Goncalves, M. (2009). Learning orthography in adulthood: A magnetoencephalographic study. Journal of Neuropsychology, 3(1), 17-30.

Chae, S. W., \& Lee, K. C. (2013). Exploring the effect of the human brand on consumers' decision quality in online shopping: An eye-tracking approach. Online Information Review, 37, 83-100.

Daugherty, T., Hoffman, E., Kennedy, K., \& Nolan, M. (2018). Measuring consumer neural activation to differentiate cognitive processing of advertising: Revisiting Krugman. European Journal of Marketing, 52(1/2), 182-198.

Dehzangi, O., Rajendra, V., \& Taherisadr, M. (2018). Wearable driver distraction identification on-the-road via continuous decomposition of galvanic skin responses. Sensors, 18(2), 503.

de Oliveira, J. H. C. (2014). Neuromarketing and sustainability: challenges and opportunities for Latin America. Latin American Journal of Management for Sustainable Development, 1(1), 35-42.

Duan, Y., Rhodes, P. A., \& Cheung, V. (2018). The influence of color on impulsiveness and arousal: Part 1-Hue. Color Research \& Application, 43(3), 396-404.s

Duchowski, A. T. (2007). Eye tracking methodology. Theory and practice, 328.

Email Wire. (2009). 'Keros client Bark Group partners with Mindmetic in new field of neuromarketing', press release, 15 December, http://emailwire.com/release/31185- Keros-Client-Bark-Group-Partners-With-Mindmetic-in-New-Field-of-Neuromarketing.html

Eser, Z., Isin, F. B., \& Tolon, M. (2011). Perceptions of marketing academics, neurologists, and marketing professionals about neuromarketing. Journal of Marketing Management, 27(7-8), 854-868.

Falk EB, Berkman ET, Lieberman MD (2012). "Effects from neural responses to population behavior: neural focus group predicts population-level media". Psychol Sci 23(5):439-445

Fisher, C. E., Chin, L., \& Klitzman, R. (2010). Defining neuromarketing: Practices and professional challenges. Harvard review of psychiatry, 18(4), 230-237.

Fiszman, B. P., Velasco, C., Salgado-Montejo, A., \& Spence, C. (2013). Using combined eye tracking and word association in order to assess novel packaging solutions: A case study involving jam jars. Food Quality and Preference, 28, 328-338. http://dx.doi.org/10.1016/j.foodqual.2012.10.006

Fortunato, V. C. R., Giraldi, J. D. M. E., \& de Oliveira, J. H. C. (2014). A review of studies on neuromarketing: Practical results, techniques, contributions and limitations. Journal of Management Research, 6(2), 201-220.

Fugate, D.L. (2007). Neuromarketing: A Layman's Look at Neuroscience and its Potential Application to Marketing Practice. Journal of Consumer Marketing, 24(7), 385-394.

Gani, M. O., Reza, S. S., Rabi, M. R. I., \& Reza, S. S. (2015, October). Neuromarketing: methodologies of marketing science. In Proceedings of The 3rd International Conference On Advances in Economics, Management and Social Study.

Gevins, A., \& Smith, M. E. (1999). Detecting transient cognitive impairment with EEG pattern recognition methods. Aviation, space, and environmental medicine, 70(10), 1018-1024.

Greenwald, A. G., Nosek, B. A., \& Banaji, M. R. (2003). Understanding and using the implicit association test: I. An improved scoring algorithm. Journal of personality and social psychology, 85(2), 197.

Hallett, M. (2000). Transcranial magnetic stimulation and the human brain. Nature, 406(6792), 147.

Hämäläinen, M.S., Hari, R. (2002). "Magnetoencephalographic characterization of dynamic brain activation: basic principles and methods of data collection and source analysis", in Toga, A.W., Mazziotta, J.C. (Eds),Brain Mapping: The Methods, Academic Press, 
New York, NY, pp.227-53.

Harmon-Jones, E., \& Allen, J. J. (1998). Anger and frontal brain activity: EEG asymmetry consistent with approach motivation despite negative affective valence. Journal of personality and social psychology, 74(5), 1310.

Haynes, J.D. and Rees, G. (2006). "Decoding mental states from brain activity in humans", Nature Reviews Neuroscience, Vol. 7 , pp. 523-534.

Heekeren, H. R., Marrett, S., \& Ungerleider, L. G. (2008). The neural systems that mediate human perceptual decision making Nature reviews neuroscience, $9(6), 467$.

Hofmann, W., Gawronski, B., Gschwendner, T., Le, H., \& Schmitt, M. (2005). A meta-analysis on the correlation between the Implicit Association Test and explicit self-report measures. Personality and Social Psychology Bulletin, 31(10), 1369-1385.

Hondrou, C., \& Caridakis, G. (2012, May). Affective, natural interaction using EEG: sensors, application and future directions. In Hellenic Conference on Artificial Intelligence (pp. 331-338). Springer, Berlin, Heidelberg.

Horvath et al.(2011). "Transcranial magnetic stimulation: a historical evaluation and future prognosis of therapeutically relevant ethical concerns". J Med Ethics 2011;37:137e143. doi:10.1136/jme.2010.039966, Published by group.bmj.com.

Houwer, J. \& Bruycker, E. (2007). The implicit association test outperorms the extrinsic affective Simon task as an implicit measure of inter-individual differences in attitudes. British Journal of Social Psychology, 46, 401-421.

Huettel, S. A., Song, A. W., \& McCarthy, G. (2004). Functional magnetic resonance imaging (Vol. 1). Sunderland, MA: Sinauer Associates.

lorga M.A. \& POP AL. N.,(2012). "A new challenges for contemporary marketing-Neuromarketing", Management \& Marketing Challenges for the Knowledge Society (2012) Vol. 7, No. 4, pp. 631-644

Karibe, H., Okamoto, A., Kato, Y., Shimazu, K., \& Goddard, G. (2018). Reliability, validity, and sex differences of a quantitative gag reflex measurement method. Journal of oral rehabilitation.

Kenning, P., \& Linzmajer, M. (2011). Consumer neuroscience: an overview of an emerging discipline with implications for consumer policy. Journal für Verbraucherschutz und Lebensmittelsicherheit, 6(1), 111-125.

Kenning, P., Plassmann, H., \& Ahlert, D. (2007). Applications of functional magnetic resonance imaging for market research. Qualitative Market Research: An International Journal, 10(2), 135-152

Khushaba, R. N., Wise, C., Kodagoda, S., Louviere, J., Kahn, B. E., \& Townsend, C. (2013). Consumer neuroscience: Assessing the brain response to marketing stimuli using electroencephalogram (EEG) and eye tracking. Expert Systems with Applications, 40(9), 3803-3812.

Koc, E., \& Boz, H. (2018). How Can Consumer Science Be Used for Gaining Information About Consumers and the Market?: The role of psychophysiological and neuromarketing research. In Case Studies in the Traditional Food Sector (pp. 129-152).

Kuan, G., Morris, T., Kueh, Y. C., \& Terry, P. C. (2018). Effects of relaxing and arousing music during imagery training on dartthrowing performance, physiological arousal indices, and competitive state anxiety. Frontiers in Psychology, 9, 14.

Lai, C. F., Lai, Y. H., Hwang, R. H., \& Huang, T. C. (2018). Physiological signals anticipatory computing for individual emotional state and creativity thinking. Computers in Human Behavior.

Laubrock, J., Engbert, R., Rolfs, M., Kliegl, R. (2007). Microsaccades are an index of covert attention: Commentary on Horowitz, Fine, Fencsik, Yurgenson, Wolfe. Psychological Science, 18, 364-366 In Zurawicki, L. (2010). Neuromarketing, Exploring the Brain of the Consumer. Berlin Heidelberg. Springer- Verlag

Lavrakas, P. J. (2008). Encyclopedia of survey research methods Thousand Oaks, CA: SAGE Publications Ltd doi: $10.4135 / 9781412963947$

Ledowski, T., Bromilow, J., Paech, M. J., Storm, H., Hacking, R., \& Schug, S. A. (2006). Monitoring of skin conductance to assess postoperative pain intensity. BJA: British Journal of Anaesthesia, 97(6), 862-865.

Lee, N., Broderick, A.J.,\&Chamberlain, L. (2007). What is 'neuromarketing'? A discussion and agenda for future research. International Journal of Psychophysiology, 63(2), 199-204.

Lewandowska, A., Borusiak, B., Dierks, C., Giungato, P., Jerzyk, E., Kurczewski, P., ... \& Witczak, J. (2018). Neuro-marketing Tools for Assessing the Communication Effectiveness of Life Cycle Based Environmental Labelling-Procedure and Methodology. In Designing Sustainable Technologies, Products and Policies (pp. 163-173). Springer, Cham.

Lewis, D. and Bridger, D. (2005). "Market Researchers make increasing use of Brain Imaging". ACNR. Vol. 5 n. 3 Pp. 36.

Retrieved from: http://www.drdavidlewis.co.uk/ass ets/NeuroMarket1.pdf on May 15th 2012

Lindstrom, Martin (2008), Buy.ology, Random House Business Books, Random House, 20 Vauxhall Bridge Road, London SW1V 2SA, ISBN 9781847940131.

Lotte, F., Congedo, M., Lécuyer, A., Lamarche, F., \& Arnaldi, B. (2007). A review of classification algorithms for EEG-based braincomputer interfaces. Journal of neural engineering, $4(2), \mathrm{R} 1$.

Lorenzo-Romero, C., Alarcón-del-Amo, M. D. C., \& Gómez-Borja, M. Á. (2016). Analyzing the User Behavior toward Electronic Commerce Stimuli. Frontiers in behavioral neuroscience, 10, 224.

Martinez, P. (2011). The consumer mind: Brand perception and the implication for marketers. London, United Kingdom: Kogan Page.

Maughan, L., Gutnikov, S., \& Stevens, R. (2007). Like more, look more. Look more, like more: The evidence from eye-tracking. Journal of Brand Management, 14(4), 335-342.

Mathis, C. A., Bacskai, B. J., Kajdasz, S. T., McLellan, M. E., Frosch, M. P., Hyman, B. T., ... \& Klunk, W. E. (2002). A lipophilic 
thioflavin-T derivative for positron emission tomography (PET) imaging of amyloid in brain. Bioorganic \& medicinal chemistry letters, 12(3), 295-298.

McBride, G., King, M. G., \& James, J. W. (1965). Social proximity effects on galvanic skin responses in adult humans. The Journal of psychology, 61(1), 153-157.

Mollen, A., \& Wilson, H. (2010). Engagement, telepresence and interactivity in online consumer experience: Reconciling scholastic and managerial perspectives. Journal of business research, 63(9-10), 919-925.

Morin, C. (2011). Neuromarketing: The New Science of Consumer Behavior, Symposium: Consumer Culture in Global Perspective, 48, 131-135.

Murphy,et.al, (2008). Neuroethics of neuromarketing, Journal of Consumer Behaviour, J. Consumer Behav. 7: 293-302 (2008),

Published online in Wiley InterScience (www.interscience.wiley.com) DOI: 10.1002/cb.252.

Nemorin, S. (2017). Neuromarketing and the "poor in world" consumer: how the animalization of thinking underpins contemporary market research discourses. Consumption Markets \& Culture, 20(1), 59-80.

Nobel, C. (2013, February 1). Neuromarketing: Tapping into the "pleasure center" of consumers. Forbes. Retrieved from http://www.forbes.com/sites/hbsworkingknowledge /2018/07/20/neuromarketing- tapping- into-the-pleasure-center-of-consumers.

Norris, S. L., \& Currieri, M. (1999). Performance enhancement training through neurofeedback. In Introduction to quantitative EEG and neurofeedback (pp. 223-240).

O'Connel, B., Walden, S., Pohlmann, A. (2011). Marketing and Neuroscience. What Drives Customer Decisions? American Marketing Association, White Paper

Ohme, R., Reykowska, D., Wiener, D. \& Choromanska, A. (2009). Analysis of neurophysiological reactions to advertising stimuli by means of EEG and galvanic skin response measures. J. Neurosci. Psychol. Econ. 2, 21-31

Orquín, J. L., \& Loose, S. M. (2013). Attention and choice: A review on eye movements in decision making. Acta Psychologica, 144, 190-206. http://dx.doi.org/10.1016/j.actpsy.2013.06.003

Page,G. (2011). "Increasing our brainpower, Using neuroscience effectively", Quirk's Marketing Research Review (www.quirks.com). Reprinted with permission from the May 2011 issue

Park, S. H., Park, J., Park, H. N., Park, H. M., \& Song, J. Y. (2018). Flexible galvanic skin response sensor based on vertically aligned silver nanowires. Sensors and Actuators B: Chemical.

Petty, R. E. (2018). Attitudes and persuasion: Classic and contemporary approaches. Routledge.

Poldrack, R.A., Fletcher, P.C., Henson, R.N., Worsley, K.J., Brett, M., Nichols, T.E. (2008). Guidelines for reporting an fMRI study. Neurolmage, 40, 409-414.

Randall, Kevin (2009). "Neuromarketing Hope and Hype: 5 Brands Conducting Brain Research | Fast Company." FastCompany.com. 14 Sept. 2009. Web. 10 June 2010.

Reimann, M., Schilke, O., Weber, B., Neuhaus, C., Zaichkowsky, J. (2011). Functional Magnetic Resonance Imaging in Consumer Research: A Review and Application. Psychology \& Marketing Wiley Periodicals, 28(6), 608-637. Paris.

Roullet, B. and Droulers, O. (2010), Neuromarketing. Le marketing revisité par les neurosciences du consommateur, DUNOD,

Saad, G. (2015). Neuromarketing. Wiley Encyclopedia of Management, 1-3.

Santos, O.R. et al. (2015). "Eye Tracking in Neuromarketing: A Research Agenda for Marketing Studies", International Journal of Psychological Studies; Vol. 7, No. 1; 2015 ISSN 1918-7211 E-ISSN 1918-722X Published by Canadian Center of Science and Education.

Sarigiannidou, C., \& Vlachakis, S. (2017, June). Neuromarketing: main approaches and future tendencies. In 5 th International Conference on Contemporary Marketing Issues ICCMI June 21-23, 2017 Thessaloniki, Greece (p. 476).

Sebastian, V. (2014). Neuromarketing and evaluation of cognitive and emotional responses of consumers to marketing stimuli.

Procedia-Social and Behavioral Sciences, 127, 753-757.

Senior, C., Smyth, H., Cooke, R., Shaw, R. L., \& Peel, E. (2007). Mapping the mind for the modern market researcher. Qualitative

Market Research: An International Journal, 10(2), 153-167.

Singh, N., \& Jain, S. (2018). Neuromarketing in Action-Towards a New Model of Persuasion. AADYA-Journal of Management and Technology (JMT), 8(1), 101-110.

Shah, P. (2005) "Neuromarketing: Smart marketing or jedi mind control trick?" Retrieved November 14, 2007, from http://www.webpronews.com/topnews/2005/06/01/ neuromarketing-smart-marketing-or-jedi-mind-control-trick

Smidts, A., Hsu, M., Sanfey, A. G., Boksem, M. A., Ebstein, R. B., Huettel, S. A., .. \& Liberzon, I. (2014). Advancing consumer neuroscience. Marketing Letters, 25(3), 257-267.

Smith, C. T., \& Nosek, B. A. (2010). Implicit association test. Corsini's Encyclopedia of Psychology, 803-804.

Stasi, A., Songa, G., Mauri, M., Ciceri, A., Diotallevi, F., Nardone, G., \& Russo, V. (2018). Neuromarketing empirical approaches and food choice: A systematic review. Food Research International, 108, 650-664

Solnais, C., Andreu-Perez, J., Sánchez-Fernández, J., \& Andréu-Abela, J. (2013). The contribution of neuroscience to consumer research: A conceptual framework and empirical review. Journal of Economic Psychology, 36, 68-81.

Suomala, J. (2018). Benefits of Neuromarketing in the Product/Service Innovation Process and Creative Marketing Campaign. In Innovative Research Methodologies in Management (pp. 159-177). Palgrave Macmillan, Cham.

Ter-Pogossian, M. M. (2017). Positron emission tomography (PET). In Three-Dimensional Biomedical Imaging (1985) (pp. 49-64). 
CRC Press.

Ulman, Y. I., Cakar, T., \& Yildiz, G. (2015). Ethical issues in neuromarketing:“I consume, therefore I am!". Science and engineering ethics, 21(5), 1271-1284

Van Dooren, M., \& Janssen, J. H. (2012). Emotional sweating across the body: Comparing 16 different skin conductance measurement locations. Physiology \& behavior, 106(2), 298-304.

Vechiatto, G., De Vico Fallani, F., Astolfi, L., Toppi, J., Cincotti, F., Mattia, D., Salinari, S., Babiloni, F. (2010). The Issues of Multiple Univariate Comparisons in the Context of Neuroelectric Brain Mapping: An Application in a Neuromarketing Experiment. Journal of Neuroscience Methods, 191, 283-289.

Vecchiato, G., Astolfi, L., De Vico Fallani, F., Toppi, J., Aloise, F., Bez, F., ... \& Mattia, D. (2011). On the use of EEG or MEG brain imaging tools in neuromarketing research. Computational intelligence and neuroscience, 2011, 3.

Velásquez, J. D. (2013). Combining eye-tracking technologies with web usage mining for identifying Website Keyobjects. Engineering Applications of Artificial Intelligence, 26, 1469-1478. http://dx.doi.org/10.1016/j.engappai.2013.01.003

Voicu,C.M.(2013). "Aspects regarding neuromarketing specific research methods"

Wang, C. C., \& Hsu, M. C. (2014). An exploratory study using inexpensive electroencephalography (EEG) to understand flow experience in computer-based instruction. Information \& Management, 51(7), 912-923.

Wang, Y.J. \& Minor, M.S. (2008). Validity, Reliability and Applicability of Psychophysiolgical Techniques in Marketing Research. Psychology \& Marketing, 25(2), 197-232.

Wedel, M., \& Pieters, R. (2008). A review of eye-tracking research in marketing. In Review of marketing research (pp. 123-147). Emerald Group Publishing Limited.

Werkle-Bergner, M., Müller, V., Li, S. C., \& Lindenberger, U. (2006). Cortical EEG correlates of successful memory encoding: Implications for lifespan comparisons. Neuroscience \& Biobehavioral Reviews, 30(6), 839-854.

Weinstein, S., Drozdenko, R., \& Weinstein, C. (1984) "Brain wave analysis in advertising research. Psychology and Marketing", 1 , 83-96.

Williams, J. (2010), Neuromarketing: When science and marketing collide. In http://info.4imprint.com/wp-content/uploads/1P-070710-July-Blue-Paper-Neuromarketing.pdf

Williams, J. (2010) "Neuromarketing: When science and marketing collide". In http://info.4imprint.com/wp-content/uploads/1P-070710-July-Blue-Paper-Neuromarketing.pdf .

Yoon, C., Gutchess, A. H., Feinberg, F., \& Polk, T. A. (2006). A functional magnetic resonance imaging study of neural dissociations between brand and person judgments. Journal of Consumer Research, 33(1), 31-40.

Zak, P. J., \& Knack, S. (2001). Trust and growth. The economic journal, 111(470), 295-321.

Ziegler I.S. (2005). "Positron Emission Tomography: Principles, Technology, and Recent Developments", Nuclear Physics A 752 (2005) 679c-687c, 0375-9474/\$,2005 Elsevier B.V. All rights reserved. doi:10.1016/j.nuclphysa.2005.02.067.

Zhao, Q., \& Koch, C. (2013). Learning saliency-based visual attention: A review. Signal Processing, 93, 1401-1407. http://dx.doi.org/10.1016/j.sigpro.2012.06.014

М. О. Гані, асистент, Університет Джахангірнагар (Савар, Бангладеш), Хіросімський університет (Хіґасі-Хіросіма, Японія);

M. 3. Алам, Ph.D., доцент, Університет підвищення кваліфікації (Дакка, Бангладеш);

Мд. М. Алом, асистент, Міжнародний університет Манарат (Дакка, Бангладеш);

M. O. Фарук, Ph.D., асистент, Університет Джаганнатх (Дакка, Бангладеш).

Проблеми та перспективи розвитку нейромаркетингу: дослідження для Бангладеш

Сучасні тенденції розвитку інформаційних технологій обумовлюють необхідність використання нових сучасних маркетингових інструментів з метою підвищення ефективності проведення рекламних кампаній організації. При цьому необхідно враховувати, як психологія споживачів та їх емоції впливають на процес прийняття рішень щодо вибору товару. Авторами зазначається актуальність використання концепиії нейромаркетингу, яка дає змогу отримати фактичні дані про споживчі вподобання групи споживачів иільового ринку. Метою дослідження $є$ вчення проблем, перспектив, обмежень та потенціалу використання нейромаркетингу як найбільш сучасного маркетингового підходу з метою надання відповідних рекомендацій для компаній з урахуванням особливостей ринкового середовища Бангладешу. Автором узагальнено основні бар'єри та обмеження розвитку нейромаркетингу в Бангладеші як в країні, що розвивається. Використання якісного та кількісного аналізу дозволило автору визначити стан, місце та перспективи використання нейромаркетингу у бізнес-середовищі Бангладешу. У рамках дослідження було проаналізовано дані 120 респондентів (55 клієнтів і 65 маркетологів). Результати дослідження свідчать, що проведення нейромаректингових кампаній вимагає наявності як кваліфрікованих спеціалістів-маркетологів, так готових сприймати інформацію споживачів. Тому автор наголошує, що освіта є одним із ключових фракторів, що впливає на поширення концепції нейромаркетингу в Бангладеші. Окрім цього, автор рекомендує проведення маркетологами ініціативних просвітницьких програм в локальних спільнотах щодо безпечності пристроїв та технологій нейромаркетингу з метою зменшення стереотипного мислення щодо їх шкідливості та небезпечності для функціонування організму людини.

Ключові слова: нейромаркетинг, маркетинг, маркетингові дослідження, споживчі переваги. 